\title{
ANALYSIS OF CHRONIC MYELOID LEUKEMIA PHARMACOTHERAPY COSTS IN POLAND
}

\author{
ANNA PACZKOWSKA ${ }^{1 *}$, KRZYSZTOF KUS ${ }^{1}$, MONIKA NOWICKA ${ }^{1}$, \\ DOROTA KOPCIUCH' ${ }^{1}$, TOMASZ ZAPRUTKO ${ }^{1}$, MIECZYSŁAW KOMARNICKI ${ }^{2}$ \\ and ELŻBIETA NOWAKOWSKA'
}

\author{
'Department of Pharmacoeconomics and Social Pharmacy, \\ Poznan University of Medical Sciences, Dąbrowskiego 79, 60-529 Poznan, Poland \\ ${ }^{2}$ Department of Hematology and Stem Cell Transplantation, \\ Poznan University of Medical Sciences, Szamarzewskiego 82/84, 60-569 Poznan, Poland
}

\begin{abstract}
The aim of this study was to analyze pharmacotherapy cost of chronic myeloid leukemia from the society's, the payer's (National Health Fund), and the patient's perspective. The study included 55 patients with a diagnosed and treated chronic myeloid leukemia at the selected hematology clinic in the city of Poznan. Retrospective study involved time horizon of one calendar year - 2013. The data required for economic evaluation were obtained from the patients' case histories and the Department of Organization and Accounting of the selected health care facilities. The total cost of chronic myeloid leukemia pharmacotherapy for 55 patients from the society's perspective in 2013 amounted to 1,483,416.88 EUR. Average annual cost of medication per patient in 2013 amounted to 26,971.22 EUR (Median - 32,854.22 EUR). Average cost of chronic myeloid leukemia pharmacotherapy for a patient without transplantation was 32,167.34 EUR (Median - 30,623.00 EUR), and for a patient after transplantation amounted to 413.13 EUR (Median - 378.40 EUR). The cost from the payer's perspective is $99.93 \%$ of total costs from the society's perspective. The cost from the patient's perspective represents $0.07 \%$ of the total cost of chronic myeloid leukemia pharmacotherapy from the society's perspective. Costs of chronic myeloid leukemia pharmacotherapy are very high and represent a significant burden to society. The highest costs associated with treatment of chronic myeloid leukemia are incurred by the society and subsequently, the public payer (NHF) and the patient.
\end{abstract}

Keywords: chronic myeloid leukemia, pharmacotherapy cost analysis, stem cell transplantation, Poland

Pharmacoeconomics is an interdisciplinary branch of knowledge combining medical science and economics, aimed at making the best use of financial resources to provide the best possible medical care. It is particularly important in treatment of diseases requiring expensive medications and diagnosis and affecting a large group of patients. Leukemia is one of such diseases where the treatment is based on a number of diagnostic tests required to diagnose and monitor the disease. The patient undergoes a long-term pharmacotherapy, and many cases involve long-term hospitalization and hematopoietic stem cells transplantation is involved (1-3). Chronic myeloid leukemia belongs to the group of the disease known as myeloproliferative neoplasms. It is a clonal proliferation of tumor derived from multipotent bone marrow stem cells of myeloid origin (4). Leukemia's account for approx.
$2 \%$ of cases of cancer in Poland. Incidence of leukemia increases with age. In women, the highest incidence is in group aged between 75 and 79 years. In contrast, the median age for the disease in men is 70-74 years. Most deaths caused by myeloid leukemia occur after the age of 55 (75\% of deaths in men and $80 \%$ in women). The risk of dying from this cancer increases with age, reaching the maximum in the sixth and eighth decade of life $(5,6)$. The current objective in the treatment of chronic myeloid leukemia is to achieve long-term, non-neoplastic hematopoiesis, that is a total molecular response to treatment. Contemporary therapy of chronic myeloid leukemia is aimed at allowing the patients to function in many areas of life, thus at improving the quality of life (7). Nowadays, there is a range of pharmacological methods available as well as transplantation of hematopoietic stem cells

* Corresponding author: e-mail: aniapaczkowska@ump.edu.pl 
(referred to as hematopoietic stem cell transplantation - HSCT). Pharmacologic agents include such drugs as busulfan, hydroxyurea, interferon alfa, and tyrosine kinase inhibitors $(7,8)$. Numerous literature data show that leukemia is a significant burden not only for the health care system but also for the society in general. For example, in Greece, it was estimated that the average annual cost of chronic myeloid leukemia treatment per patient in outpatient facilities was 22,972 EUR. Of direct medical costs of treating chronic myeloid leukemia, pharmacotherapy costs constituted the largest share (approx. 90\% of the total cost of treatment) (9). In Germany, it was estimated that the average annual cost of chronic myeloid leukemia treatment per patient in 2007 and 2008 from the payer's perspective amounted to 9,753 EUR and 13,939 EUR from the social perspective. The total economic burden of chronic lymphocytic leukemia therapy for the payer exceeded $201 \mathrm{~m}$ EUR per year and for the society 322 m EUR per year (10). In Poland, according to the references, there is no sufficient analysis of chronic myeloid leukemia treatment costs. Analysis of availability of cancer treatment and financing services in chemotherapy, conducted in 2012 by the Institute of Healthcare Organizations at Lazarski University, indicates that value of contracts con- cluded by the National Health Fund with healthcare providers for treatment of chronic myeloid leukemia in 2012 amounted to over 53 m EUR (11).

The aim of this study was to analyze the chronic myeloid leukemia pharmacotherapy cost from the social, the payer's (National Health Fund), and the patient's perspective. The study also included a comparative analysis of the chronic myeloid leukemia pharmacotherapy costs for patients after hematopoietic cell transplantation with the costs of treating patients without transplantation.

\section{EXPERIMENTAL}

Analysis of the chronic myeloid leukemia pharmacotherapy cost was based on medical data comprising medical histories of patients with chronic myeloid leukemia treated at the Department of Hematology and Stem Cell Transplantation, Poznan University of Medical Sciences in Poland. The study design was approved by the local Ethics Committee and the Hospital's Management.

\section{Time horizon}

We analyzed the cost of treating patients undergoing treatment over one calendar year - 2013 (01/01./2013-31/12/2013).

Table 1. Characteristics of the study group.

\begin{tabular}{|c|c|c|}
\hline \multicolumn{2}{|c|}{ Variables } & Value \\
\hline \multirow{3}{*}{$\begin{array}{l}\text { Population } \\
\text { [n] }\end{array}$} & General & 55 \\
\hline & Women & 34 \\
\hline & Men & 21 \\
\hline \multirow{3}{*}{$\begin{array}{l}\text { age } \\
{\left[\text { age, } \mathrm{M}^{1} \pm \mathrm{SD}^{2}, \mathrm{Med}\right]}\end{array}$} & General & $\begin{array}{l}59 \pm 13.3 \\
\text { Med [62] }\end{array}$ \\
\hline & Women & $\begin{array}{l}61 \pm 13.5 \\
\text { Med }[66]\end{array}$ \\
\hline & Men & $\begin{array}{l}57 \pm 13.0 \\
\text { Med [52] }\end{array}$ \\
\hline $\begin{array}{l}\text { Patients after hematopoietic cell } \\
\text { transplantation }[\%]\end{array}$ & General & 16 \\
\hline \multicolumn{3}{|l|}{ Comorbidities present [\%]: } \\
\hline -hypertension & \multirow{6}{*}{ General } & 18 \\
\hline -obesity & & 15 \\
\hline -congestive heart failure & & 5 \\
\hline -heart arrhythmia & & 11 \\
\hline -asthma & & 7 \\
\hline -lipid disorders & & 13 \\
\hline
\end{tabular}

${ }^{1}$ M-Average; ${ }^{2}$ SD-Standard deviation; Med-Median 
Table 2. Drugs used in pharmacotherapy of chronic myeloid leukemia patients without hematopoietic cells transplantation.

\begin{tabular}{|l|c|c|}
\hline $\begin{array}{c}\text { International name } \\
\text { of the drug }\end{array}$ & $\begin{array}{c}\text { Active } \\
\text { substance }\end{array}$ & $\begin{array}{c}\text { Number of patients } \\
\text { receiving the drug [n] }\end{array}$ \\
\hline Imatinib & Imatynibum & 42 \\
\hline Nilotinib & Nilotynibum & 9 \\
\hline Hydroxycarbamide & Hydroxycarbamidum & 5 \\
\hline Dasatinib & Dasatynibum & 4 \\
\hline Interferon alfa-2b & Interferon alfa-2b & 1 \\
\hline
\end{tabular}

Having analyzed case histories of 365 patients diagnosed with myeloid leukemia, 55 patients were included in the study based on the following strict inclusion and exclusion criteria.

\section{Study inclusion criteria}

1. diagnosed and treated chronic myeloid leukemia in the analyzed time period.

2. age from 18 to 80 .

\section{Study exclusion criteria}

1. age under 18 and over 80 ;

2. no follow-up treatment of chronic myeloid leukemia in the analyzed time horizon.

\section{Research perspective}

Analysis of chronic myeloid leukemia pharmacotherapy costs adopted the social, the payer's (National Health Fund), and the patient's perspective.

The analyzed medical data related to the history of the disease and methods of patients treatment with chronic myeloid leukemia. Information on the drugs used and dosing regimens applied was collected. Data relating to prices of anticancer drugs in 2013 were obtained from the Wielkopolska Branch of the National Health Fund in Poznan. In order to calculate the cost of drugs to support medical therapy for chronic myeloid leukemia among the study patients, average retail prices of drugs and prices of the refund applicable in the examined time horizon were obtained.

The cost of medication per patient is calculated using the following formula:

$$
\mathrm{Kf}=\mathrm{T} \times \mathrm{Dw} \times \mathrm{Ld}
$$

where: $\mathrm{Kf}$ - cost of pharmacotherapy using a specific drug in the analyzed time horizon, $\mathrm{T}$ - cost of a single tablet, Dw - daily dosage, Ld - number of days on which the drug is taken.

The estimated costs are presented in EUR, according to the table of annual average weighted foreign exchange rates of the National Bank of Poland (EUR 1 = PLN 4.1975) (12).

\section{RESULTS}

\section{Characteristics of the study group}

A group of 55 patients with a diagnosed chronic myeloid leukemia and treated in 2013 consisted of 34 women and 21 men. Mean age of the patients in the study group was $59 \pm 13.3$ years. The most common comorbidities among the study patients included: hypertension (33\%), obesity (27\%), dyslipidemia ( $24 \%$ of respondents) and cardiac arrhythmia (20\% of respondents). $16 \%$ of patients with chronic myeloid leukemia, underwent hematopoietic cells transplantation (Table 1).

Analysis of chronic myeloid leukemia pharmacotherapy costs from the patient's, the payer's, and the social perspective.

In the pharmacotherapy of chronic myeloid leukemia, the following drugs were used in patients without hematopoietic cells transplantation: Imatinib, Nilotinib, Hydroxycarbamide, Dasatinib, Interferon alfa-2b (Table 2).

Drugs used in the pharmacotherapy of chronic myeloid leukemia of patients after hematopoietic cells transplantation to prevent rejection of bone marrow transplant and of immunocompromised patients include Aciclovir, Phenoxymethylpenicillin, Co-trimoxazole, Ciclosporin, Pneumococcal Vaccine, Amoxicillin, Clavulanic acid, Mycophenolate Mofetil, Ciprofloxacin, Prednisone, Allopurinol (Table 3).

Prices of anticancer drugs (Imatinib, Nilotinib, Dasatinib, and Interferon alfa-2b) were obtained from the Wielkopolska Branch of the National Health Fund in Poznan. The upper limit of funding for each drug was equal to the gross wholesale price at which the hospital purchased the drug. The patients received these agents for free (Table 4).

Prices of Hydroxycarbamide checked on the reimbursable drugs list applicable in 2013 (Table 5). 
Prices of drugs used in pharmacotherapy of chronic myeloid leukemia of patients after hematopoietic cells transplantation in the case of reimbursable drugs were based on the average prices applicable, in accordance with the reimbursed drugs lists applicable in 2013, while in the case of non-reimbursable drugs average retail prices of three pharmacies in the city of Poznan were used (Table 6).

The total chronic myeloid leukemia pharmacotherapy cost from the social perspective in 2013 for the 55 study patients amounted to $1,483,416.88$
EUR. The average annual cost of medication per patient in the analyzed time horizon was $26,971.22$ EUR (Median - 32,854.10 EUR). It was estimated that the average chronic myeloid leukemia pharmacotherapy cost for patients without a transplant was 32,167.34 EUR (Median - 30,623.00 EUR), while for the patients after transplantation it was 413.13 EUR (Median - 378.40 EUR) (Table 7).

The total chronic myeloid leukemia pharmacotherapy cost from the payer's perspective amounted to $1,482,409.31$ EUR, while the average annual

Table 3. Drugs used in the pharmacotherapy of chronic myeloid leukemia patients after hematopoietic cells transplantation.

\begin{tabular}{|l|c|c|}
\hline \multicolumn{1}{|c|}{$\begin{array}{c}\text { International name } \\
\text { of the drug }\end{array}$} & $\begin{array}{c}\text { Active } \\
\text { substance }\end{array}$ & $\begin{array}{c}\text { Number of patients } \\
\text { receiving the drug [n] }\end{array}$ \\
\hline Aciclovir & Aciclovir sodium & 9 \\
\hline Phenoxymethylpenicillin & $\begin{array}{c}\text { Phenoxymethylpenicillin } \\
\text { potassium }\end{array}$ & 7 \\
\hline Co- trimozazole & $\begin{array}{c}\text { Sulfamethoxazolum }+ \\
\text { trimethoprimum }\end{array}$ & 6 \\
\hline Ciclosporin & Ciclosporinum & 4 \\
\hline Pneumococcal Vaccine & Pneumococcal vaccine & 3 \\
\hline Amoxicillin, & Amoxicillinum + acidum \\
Clavulanic acid & Mycophenolate mofetil & 1 \\
\hline Mycophenolate Mofetil & Ciprofloxacinum hydrochloride & 1 \\
\hline Ciprofloxacin & Prednisonum & 1 \\
\hline Prednisone & allopurinolum & 1 \\
\hline Allopurinol & & \\
\hline
\end{tabular}

Table 4. Prices of drugs used in pharmacotherapy of chronic myeloid leukemia patients without a transplant.

\begin{tabular}{|l|c|}
\hline \multicolumn{1}{|c|}{ International name of the drug } & Price in 2013 [EUR] \\
\hline Imatinib $\left(100 \mathrm{mg}^{1}, 60\right.$ tablets $)$ & 1133.40 \\
\hline Imatinib (400 mg, 30 tablets) & 2266.72 \\
\hline Nilotinib (200 mg, 112 capsules) & 3705.14 \\
\hline Dasatinib (100 mg, 30 tablets) & 3537.90 \\
\hline Interferon alfa-2b $(25 \mathrm{~m}$ IU / $2.5 \mathrm{~mL})$ & 105.95 \\
\hline
\end{tabular}

${ }^{1} \mathrm{mg}$ - milligrams

Table 5. Prices of drugs used in pharmacotherapy of chronic myeloid leukemia among patients without a transplant.

\begin{tabular}{|c|c|c|}
\hline \multirow[b]{2}{*}{ International name of the drug } & \multicolumn{2}{|c|}{ Price in 2013} \\
\hline & $\begin{array}{l}\text { National Health Fund's co-payment } \\
\text { [EUR] }\end{array}$ & $\begin{array}{c}\text { Patient's co-payment } \\
\text { [EUR] }\end{array}$ \\
\hline $\begin{array}{c}\text { Hydroxycarbamide } \\
\text { (100 capsules) }\end{array}$ & 19.01 & 0.00 \\
\hline
\end{tabular}


Table 6. Prices of drugs used in pharmacotherapy of chronic myeloid leukemia of patients after transplantation.

\begin{tabular}{|l|c|c|}
\hline \multirow{2}{*}{$\begin{array}{c}\text { Trade name of the drug (international } \\
\text { name of the drug) }\end{array}$} & $\begin{array}{c}\text { Pational Health } \\
\text { Fund's co-payment } \\
\text { [EUR] }\end{array}$ & $\begin{array}{c}\text { Patient's } \\
\text { co-payment } \\
\text { [EUR] }\end{array}$ \\
\cline { 2 - 3 } & 3.81 & 2.96 \\
\hline Aciclovir (400 mg', 30 tablets) & 5.93 & 5.93 \\
\hline Aciclovir (800 mg, 30 tablets) & 1.38 & 0.93 \\
\hline Phenoxymethylpenicillin (1000 mg, 12 tablets) & 0.00 & 4.94 \\
\hline Co- trimozazole (160 mg + 800 mg, 10 tablets) & 17.24 & 1.07 \\
\hline Ciclosporin (25 mg, 50 tablets) & 34.46 & 0.76 \\
\hline Ciclosporin (50 mg, 50 tablets) & 0.00 & 17.85 \\
\hline Pneumococcal Vaccine & 3.89 & 3.91 \\
\hline Amoxicillin, Clavulanic acid (1000 mg, 14 tablets) & 86.70 & 0.76 \\
\hline Mycophenolate Mofetil (250 mg, 50 tablets) & 86.70 & 0.76 \\
\hline Mycophenolate Mofetil (500 mg, 50 tablets) & 0.95 & 1.61 \\
\hline Ciprofloxacin (500 mg, 10 tablets) & 3.79 & 0.00 \\
\hline Prednisone (20 mg, 20 tablets) & 2.06 & 0.76 \\
\hline Allopurinol (100 mg, 50 tablets) & 3.62 & 0.76 \\
\hline Allopurinol (300 mg, 30 tablets) & & \\
\hline
\end{tabular}

${ }^{1} \mathrm{mg}$ - milligrams

Table 7. Analysis of chronic myeloid leukemia pharmacotherapy costs from the social perspective.

\begin{tabular}{|l|c|}
\hline \multicolumn{1}{|c|}{$\begin{array}{c}\text { The chronic myeloid leukemia pharmacotherapy } \\
\text { cost from the social perspective }\end{array}$} & $\begin{array}{c}\text { Costs in 2013 } \\
\text { [EUR] }\end{array}$ \\
\hline Patients without a transplant $(\mathrm{n}=46)$ & $1,479,698.74$ \\
\hline $\begin{array}{l}\text { Average annual cost per patient without a } \\
\text { transplant }\left[\mathrm{M}^{1} \pm \mathrm{SD}^{2}, \mathrm{Med}\right]\end{array}$ & $\begin{array}{c}32,167.34 \pm 8,953.92 \\
\text { Med [30,623.00] }\end{array}$ \\
\hline Patients after transplantation $(\mathrm{n}=9)$ & $3,718.15$ \\
\hline $\begin{array}{l}\text { Average annual cost per patient after } \\
\text { transplantation }[\mathrm{M} \pm \mathrm{SD}, \text { Med] }\end{array}$ & $\begin{array}{c}413.13 \pm 37.19 \\
\text { Med }[378.40]\end{array}$ \\
\hline $\begin{array}{l}\text { Total chronic myeloid leukemia } \\
\text { pharmacotherapy cost }\end{array}$ & $1,483,416.88$ \\
\hline $\begin{array}{l}\text { Average annual chronic myeloid leukemia } \\
\text { pharmacotherapy cost per patient }[\mathrm{M} \pm \mathrm{SD}, \mathrm{Med}]\end{array}$ & $26,971.22 \pm 6,482.13$ \\
\hline
\end{tabular}

$\mathrm{M}^{1}$ - Average; $\mathrm{SD}^{2}$ - Standard deviatio; Med - Median

cost per patient was 26,952.89 EUR (Median 33,583.20 EUR) (Table 8). The costs calculated from the social and the payer's perspective are comparable.

Total chronic myeloid leukemia pharmacotherapy cost from the patient's perspective was amounted to 1007.58 EUR, while average annual chronic myeloid leukemia pharmacotherapy cost per patient amounted to 18.32 EUR (Median - 16.20 EUR) (Table 9).

\section{DISCUSSION AND CONCLUSION}

In the present survey, chronic myeloid leukemia pharmacotherapy cost was calculated from three perspectives: the social, payer's and patient's perspective. Total chronic myeloid leukemia pharmacotherapy cost from the social perspective amounted to 1,483,416.88 / 26,971.22 EUR (Median - 33,854.10 EUR) per patient, from the payer's perspective the expenses amounted to 
1,482,409.31 / 26,952.89 EUR (Median - 33,583.20 EUR) per patient, and from the patient's perspective the chronic myeloid leukemia pharmacotherapy costs amounted to 1007.58 / 18.32 EUR (Median 16.20 EUR) per patient.

Analysis of the cost of treating chronic myeloid leukemia carried out in Greece in the time horizon of five years (2007-2011) has shown that average annual cost of treatment for a patient treated at outpatient facilities was 22,972 EUR. This cost included the cost of medications, the cost of medical visits, laboratory tests and imaging. Of direct medical costs of chronic myeloid leukemia, pharmacotherapy costs constituted the largest share (approx. 90\% of the total cost of treatment). Average cost of treating chronic myeloid leukemia differed significantly between years. In 2011, it was 8,339 EUR per patient, and in 2007 - 14,652 EUR. The study authors found that innovative treatment of chronic myeloid leukemia reduces the incidence of adverse drug reactions, thus reducing the cost of treatment (9).

Budget Impact analysis of chronic myeloid leukemia treatment in Bulgaria has shown that average annual pharmacotherapy costs (medicines plus treatment of adverse drug reactions) per patient in chronic phase using Nilotinib was approximately 66,770.90 BGN (34,140.34 EUR), using Dasatinib in dose $100 \mathrm{mg}$ was approximately $84,960.73 \mathrm{BGN}$ $(43,440.90$ EUR), using high dose Imatinib was approximately $117,586.86$ BGN (60,122.82 EUR). The budget impact analysis of the chronic myeloid leukemia therapy for patients in chronic and accelerated phase confirmed that for both groups of patients the lowest therapy costs were those with nilotinib, followed by those with high dose imatinib (13). In United States analysis of the healthcare costs among newly diagnosed patients with chronic myeloid leukemia has shown that average monthly cost per patient in 2014 year using Dasatinib was approximately 10,341 USD (8,841.08 EUR), using Nilotinib was approximately 9,611 USD (8,216.96 EUR) (14). Comparison of chronic myeloid leukemia pharmacotherapy costs in the cost-of-treatment studies in different countries leads to the conclusion that the differences are very large. The causes of this situation should be sought in the differences in health care systems in individual countries, their different economic and social situation, different drug policies, as well as differences in costs arising mainly from clinical characteristics of the study patients and from application of different standards

Table 8. The chronic myeloid leukemia pharmacotherapy cost from the payer's perspective.

\begin{tabular}{|l|c|}
\hline $\begin{array}{c}\text { The chronic myeloid leukemia pharmacotherapy } \\
\text { cost from the payer's perspective }\end{array}$ & $\begin{array}{c}\text { Costs in 2013 } \\
\text { [EUR] }\end{array}$ \\
\hline Patients without a transplant $(\mathrm{n}=46)$ & $1,479,683.66$ \\
\hline Patients after transplantation $(\mathrm{n}=9)$ & $2,725.64$ \\
\hline $\begin{array}{l}\text { Total chronic myeloid leukemia } \\
\text { pharmacotherapy cost }\end{array}$ & $1,482,409.31$ \\
\hline $\begin{array}{l}\text { Average annual chronic myeloid leukemia } \\
\text { pharmacotherapy cost per patient }\left[\mathrm{M}^{1} \pm \mathrm{SD}^{2}, \mathrm{Med}\right]\end{array}$ & $\begin{array}{c}26,952.89 \pm 6,176.26 \\
\text { Med }[33,583.20]\end{array}$ \\
\hline
\end{tabular}

$\mathrm{M}^{1}$ - Average; $\mathrm{SD}^{2}$ - Standard deviation; Med - Median

Table 9. The chronic myeloid leukemia pharmacotherapy costs from the patient's perspective.

\begin{tabular}{|l|c|}
\hline \multicolumn{1}{|c|}{$\begin{array}{c}\text { The chronic myeloid leukemia pharmacotherapy } \\
\text { cost from the patient's perspective. }\end{array}$} & $\begin{array}{c}\text { Costs in 2013 } \\
\text { [EUR] }\end{array}$ \\
\hline Patients without a transplant $(\mathrm{n}=46)$ & 15.06 \\
\hline Patients after transplantation $(\mathrm{n}=9)$ & 992.52 \\
\hline $\begin{array}{l}\text { Total chronic myeloid leukemia } \\
\text { pharmacotherapy cost }\end{array}$ & 1007.58 \\
\hline $\begin{array}{l}\text { Average annual chronic myeloid leukemia } \\
\text { pharmacotherapy cost per patient }\left[\mathrm{M}^{1} \pm \mathrm{SD}^{2}, \mathrm{Med}\right]\end{array}$ & $\begin{array}{l}18.32 \pm 4.14 \\
\text { Med }[16.20]\end{array}$ \\
\hline
\end{tabular}

$\mathrm{M}^{1}$ - Average; $\mathrm{SD}^{2}$ - Standard deviation; Med - Median 
of chronic myeloid leukemia treatment $(9,10,15)$. According to the study data, the greatest share of costs associated with chronic myeloid leukemia pharmacotherapy is paid by the society and the public payer (NHF) and the smallest share is paid by the patients. The chronic myeloid leukemia pharmacotherapy cost from the payer's perspective is $99.93 \%$ of total costs from the social perspective while the cost from the patient's perspective amounts to $0.07 \%$ of the total chronic myeloid leukemia pharmacotherapy cost from the social perspective.

The difference in the cost of medication from the payer's and the social perspectives is small because of the almost total reimbursement of drugs used in pharmacotherapy of chronic myeloid leukemia by the NHF. The total chronic myeloid leukemia pharmacotherapy cost from the patient's perspective when compared to the cost implications for the society or the payer is very low. This difference in cost arises from the fact that the patients receive most of the drugs used in pharmacotherapy of chronic myeloid leukemia for free. The total chronic myeloid leukemia pharmacotherapy cost from the patient's perspective calculated in this study results almost entirely from the costs that must be borne by the patient after bone marrow transplantation to buy medicines preventing organ rejection and infections, mostly of the respiratory tract, which may be caused by reduced immunity. These drugs, however, are also subject to reimbursement by the National Health Fund or sold for a small flat fee $(16,17)$.

The high chronic myeloid leukemia pharmacotherapy cost in the study is due to very high prices of the three pharmaceutical agents used by the patients. The most expensive drugs for chronic leukemia are anticancer drugs: Dasatinib, Nilotinib, and Imatinib. In Poland, according to the latest data, average annual chronic myeloid leukemia pharmacotherapy cost per patient using Imatinib is approximately 26,999 EUR (18) while in the US average annual per patient cost of Imatinib amounted to 92,000 USD (67,481 EUR), 54,000 USD in Germany $(39,608 \mathrm{EUR})$, and $31,000 \mathrm{USD}$ in Italy $(22,738$ EUR) (19). As shown by the above data, the cost of chronic myeloid leukemia pharmacotherapy with the same drug varies greatly between countries. In Poland, this cost is two and a half times smaller and in Italy three times smaller than in the United States. Diversified prices of cancer drugs are also due to different drug policies in place in individual countries.

Costs of chronic myeloid leukemia pharmacotherapy with tyrosine kinase inhibitors for the study patients in 2013 amounted to 0 EUR the patient's perspective because these drugs have been fully reimbursed by the National Health Fund. 30day treatment with tyrosine kinase inhibitors in the United States in 1997-2009, meanwhile, was associated with an average annual cost for the patient of 710 EUR. The average annual cost of pharmacotherapy with Imatinib only in the years 2002-2011 amounted to 1,172 EUR. Co-payment amount depended on the patient's insurance. It is worth noting that $17 \%$ of the patients with a higher co-payment for the drug and $10 \%$ with a lower co-payment abandoned treatment within the first three months of starting the pharmacotherapy $(20,21)$.

In Poland, health insurance is obligatory and is calculated on the basis of earnings. Health insurance grants all the insured persons access to identical health benefits, and the amount of reimbursement of medicines depends on therapeutic indications. Therefore, all the insured patients included in the study received a tyrosine kinase inhibitor drug for free $(1,22)$.

Prices of anticancer drugs in the United States are very high and unstable (variables). In 2001, an average annual cost of treating chronic myeloid leukemia using Novartis Glivec (Imatinib) was 27,130 EUR, and increased in 2012 rose to an exorbitant amount of 83,198 EUR even though the price of 27,130 EUR in 2001 took into account all the costs associated with the development of a new drug. This is an example of free market economy in the United States and the failure of the government and insurers in price negotiations regarding pharmaceuticals, as opposed to the practice and procedures in the other countries of the world. In Germany, since January 2011, new regulations regarding restructuring of the pharmaceutical market have been adopted according to which the prices of new drugs are determined according to their advantages compared to other drugs with the same indications available on the market (19). The Polish health care system is currently implementing an algorithm for assessment of the value of new anticancer drugs, to assist in the existing decision-making processes for cancer drugs funding. The above-mentioned algorithm could in particular be used in the mechanism of early access, enabling treatment of patients with certain drugs before making them actually available in the drug program. The use of this algorithm could also provide additional support for the Economic Commission of the Ministry of Health in the process of determining the official selling prices for new anticancer drugs or new indications for drugs already subject to reimbursement (17). 
The work of more than 100 experts and financial analysts on the prices of medicines for chronic myeloid leukemia clearly states that the prices of anticancer drugs are too high and represent a significant financial burden on any country's health care which, in turn, may restrict the patient's access to effective therapy. In African and Latin American countries, whose governments cannot afford to burden their budgets with such expensive drugs where allogeneic stem cell transplantation is considered the first line of treatment. This is a one-time procedure with the cost ranging from 27,130 EUR to 72,346 EUR. The effect, however, may be harmful in some cases due to complications or premature death (19). In the present survey, average annual chronic myeloid leukemia pharmacotherapy cost from the social perspective was significantly lower among patients after hematopoietic stem cell transplantation, at 413.13 EUR (Median - 378.40 EUR) while for the patients without a hematopoietic stem cell transplantation it was 32,167.34 EUR (Median 30,623.00 EUR). According to data from the National Health Fund the total cost of hematopoietic stem cell transplantation from a compatible sibling HLA in 2013 amounted to 29,181.82 EUR. However, the total cost of hematopoietic stem cell transplantation from an alternative donor in 2013 in Poland amounted to 59,621.38 EUR. The costs of hematopoietic stem cell transplantation, despite its high price, account for about $9 \%$ of the total cost of treatment. This disproportion in the distribution of costs results from the small number of bone marrow transplantations performed and from the fact that it is a one-time procedure (23). The indications for HSCT and the selection of the donor are determined by the diagnosis, the subtype of the disease (including risk factors for progression), the age and biological condition of the patient. The upper age limit for autoHSCT (stem cells come from the patient) is usually 65 years and for alloHSCT (stem cells come from a member of the sick family or from an unrelated donor) with myeloablative preparation - 55 years. The most common indication for alloHSCT are leukemias and myelodysplastic syndromes, and for autoHSCT - lymphomas (especially myeloma plasmacytoma). Autologous transplants are considered as an option for some solid tumors (24).

During the International Society for Pharmacoeconomics and Outcomes Research (ISPOR) $19^{\text {th }}$ Annual European Congress in Vienna in 2016, the results of a systematic review of economic burden associated with chronic myeloid leukemia in the United States were presented. Total annual cost of patients on Imatinib and with high adherence was
52,552-65,093 USD with moderate adherence was $58,854-68,125$ USD, and with low adherence was $114,759-163,387$ USD, however the cut - off of various levels of adherence differed by study. Annual cost (inpatient and outpatient) for adverse events was 17,927 USD for femoral arterial stenosis and 15,966 USD for peripheral arterial occlusive disease among tyrosine kinase inhibitors users. The cost associated with the most prevalent comorbidities such as heart disease was 2,685 USD, diabetes was 1,669 USD and lung disease was 2,004 USD (25). In summary, chronic myeloid leukemia pharmacotherapy costs are high and are a significant burden on society. The same opinion is shared by researchers from other countries, such as the United States, Canada, Argentina, Germany, France, Norway, China, Russia, and Australia (19-21).

Based on the study it can be concluded that the cost of treating chronic myeloid leukemia is a significant burden on society. The greatest share of costs associated with the treatment of pharmacotherapy of chronic myeloid leukemia is incurred by the society, followed by the public payer (NHF), and the patient. The chronic myeloid leukemia pharmacotherapy cost from the payer's perspective is much higher than from the patient's perspective and represents more than $99.93 \%$ of the costs for the society.

In Poland, allogeneic transplantation is currently used as a therapeutic method in chronic myeloid leukemia, which is not only effective but also reduces the total cost of treatment of chronic myeloid leukemia, thereby allowing the rational use of the limited health funds.

\section{Conflict of interests}

Reported no conflicts of interest.

\section{REFERENCES}

1. Nowakowska E.: Pharmacoeconomics (2nd ed.)., pp. 55-61, Scientific Publisher Poznan University of Medical Sciences, Poznan 2010 (in Polish).

2. Czech M.: (2008) Pharmacoeconomics in pharmaceutical care, pp. 89-110, Scientific Publisher Farmapress, Warsaw 2008 (in Polish).

3. Dix Smith M.: Lexicon of basic concepts ISPOR. Costs, quality and results in health care, Polish Pharmacoeconomic Society (PTFE) ISPOR Polish Chapter, Warsaw 2009 (in Polish).

4. Ferdinand R., Mitchell S., Batson S., Tumur I.: J. Blood Med. 3, 51 (2012). 
5. http://www.onkologia.org.pl.

6. http://www.epid.coi.waw.pl/coi/.

7. Nowak W., Skotnicki A.: Basics of hematology., pp. 121-130, Practical Medicine, Krakow 2011 (in Polish).

8. Bansal S.: South Asian J. Cancer 3, 83 (2014).

9. Geitona M., Hatzikou M., Gigantes S., Konstantinidou M., Solakidi A., Harhalakis N.: Value Health 15, A277-A575 (2012).

10. Blankart C.R., Koch T., Linder R., Verheyen F., Schreyogg J., Stargardt T.: Orphanet J. Rare Dis. 8, 32 (2013).

11. Wiciak-Obrębska M., Gierczyński J., Gryglewicz J., Drapała A., Parol T.: Analysis of access to cancer treatment and financing services in the field of chemotherapy in 2012., pp. 28-35, Lazarski University, Warsaw 2013 (in Polish).

11. http://www.nbp.pl/home.aspx?f=/kursy/arch_a. html.

12. Savova A., Kamusheva M., Georgieva S., Stoimenova A., Petrova G.: Biotechnol. Biotechnol. Equip. 27, 1 (2013).

13. Latremouille - Viau D., Guerin A., Nitulescu R., Gagnon P.S., Joseph G.J., Chen L.: J. Med. Econ 20, 63 (2017).

14. Hermanowski T., Jaworski R., Czech M., Pachocki R.: Arterial Hypertension 5, 83 (2001) (in Polish).
15. The availability of innovative cancer drugs in Poland and in European Union countries and Switzerland. Report prepared for the Alivia Cancer Foundation Young People by EY Poland, April (2015) (in Polish).

16. Krzakowski M., Wysocki P., Jassem J., Krzemieniecki K., Potemski P., Zyśk R.: Oncology Clin. Pract. 11, 9 (2015) (in Polish).

17. http://www.przychodnia.pl/rbt/index40.php3? $\mathrm{s}=3 \& \mathrm{~d}=6 \& \mathrm{t}=40 \& \mathrm{p} 1=7$.

18. Experts in Chronic Myeloid Leukemia.: The American Society of Hematology 121, 4439 (2011).

19. Dusetzina S.B., Winn A.N., Abel G.A., Huskamp H.A., Keating N.L.: J. Clin. Oncol. 32, 306, (2014).

20. Darkow T., Maclean R., Geoffrey F., JoyceF., Goldman D., Lakadawalla D.: Am. J. Manag. Care 18, 272 (2012).

21. http://www.mz.gov.pl/.

22. https://prog.nfz.gov.pl.

23. Giebel S.: Transplantation of hematopoietic stem cells. Recommendations for diagnostic and therapeutic procedures in malignant tumors, pp.527-530, Warsaw 2013 (in Polish).

24. Gala S., Shah A., Narayanan S.: Economic burden associated with chronic myeloid leukemia (CML) treatments in the United States, $19^{\text {th }}$ Annual European Congress, Vienna 2016.

Received: 29.05. 2018 